\title{
Trying to Identify some Ancient Residences in Albania through Old Maps
}

\author{
Prof. Dr. Agim Shehu' \\ Assist. Prof. Dr. Ferim Gashi ${ }^{2 *}$ \\ Prof. Dr. Pal Nikolli ${ }^{1}$ \\ ${ }^{2}$ University of Prishtina, Prishtina, Kosovo \\ ${ }^{1}$ University of Tirana, Tirana, Albania \\ *Corresponding Author
}

Doi: 10.36941/ajis-2020-0045

\begin{abstract}
This paper attempts to identify ancient settlements in Albania by cartographic methods by elaborating geographical coordinates obtained from Ptolemy's work. The results of the paper are of interest for archeology, history, geography, geodesy, photogrammetry etc. The problem addressed is not simple, as for some settlements, different literature sources give different values of geographical coordinates. In this context, those geographic coordinate systems that best deal with the real position of these settlements are selected. Thus, for example, the longitude ( $L$ ) of Ohrid (which serves as a support point), in some sources is given the value $L_{1}=46040$ ', while in later sources it is given the value $L_{2}=47040^{\prime}$. The calculations are performed for both cases of this longitude, but greater certainty is given when $\mathrm{L}_{2}=4704 \mathrm{O}$ 'is obtained, because the geographical longitude of Skopje (Scupi with $L=48030^{\prime}$ ), Prishtina (Ulpiana, with $L=48040$ '), Peja (Siparantum, with $\left.L=46030^{\prime}\right)$, etc., are closer to reality than $L=46040$ ', according to which Ohrid appears to be highly displaced to the west, in relation to the aforementioned sites (pic. 2.1). Consequently, settlements located in and near the Apollo - Orikum-Ohrid triangle are identified with other sites (as noted in the following statements). All of these anomalies and others such as these have been handled carefully and according to a logical rationale for the material being processed, taking into account all factors that positively impact the settlement identification process.
\end{abstract}

Keywords: archeology, history, geography, geodesy, photogrammetry, geographical coordinates, cartographic methods, Putzger, Kiepert, ancient settlements, Albania

\section{Determination of Base Locations and Settlements Identified on Ptolemy's Maps}

After 1444, in Europe during the XV-XIX centuries, Ptolemy's maps were reprinted nearly 50 times, preserving the type of cartographic projection and some values of geographical coordinates. Of interest are maps elaborated by Gastaldi (v.1560), Sofjano (v.1579), Coronel (v. 1689), Kantel (v.1689), Baudrant (v.1716), Lapie (v.1828), Weis (v.1829), Wilberg (v.1867), Kiepert (v.1871), Putzger (v.1897) etc. This study records the work done by institutions and authors that provide greater accuracy and veracity of the coordinates, compared to the values of the geographical coordinates given by other authors, such as: values of geographical coordinates given by the former Institute of History and Linguistics (some of the geographical coordinates of this paper have been corrected and corrected); Wilberg map (fig. 2.1); Kiepert's map (fig. 2); Putzger's map (fig. 2.3) and Sofiano's map (fig. 2.4). 
In order to carry out the identification, the settlements whose geographical coordinates are known in both coordinate systems were initially selected. In the coordinate system they are accepted by Ptolemy and in the Gauss-Kryger system, for the creation of topographic maps, published by the Military Geographical Institute in Tirana, during the second half of the 2oth century.

Picture 2.1 shows the base locations, while Picture 2.2 gives the geographical coordinates of the identified settlements, or for which doubts and disputes have arisen.

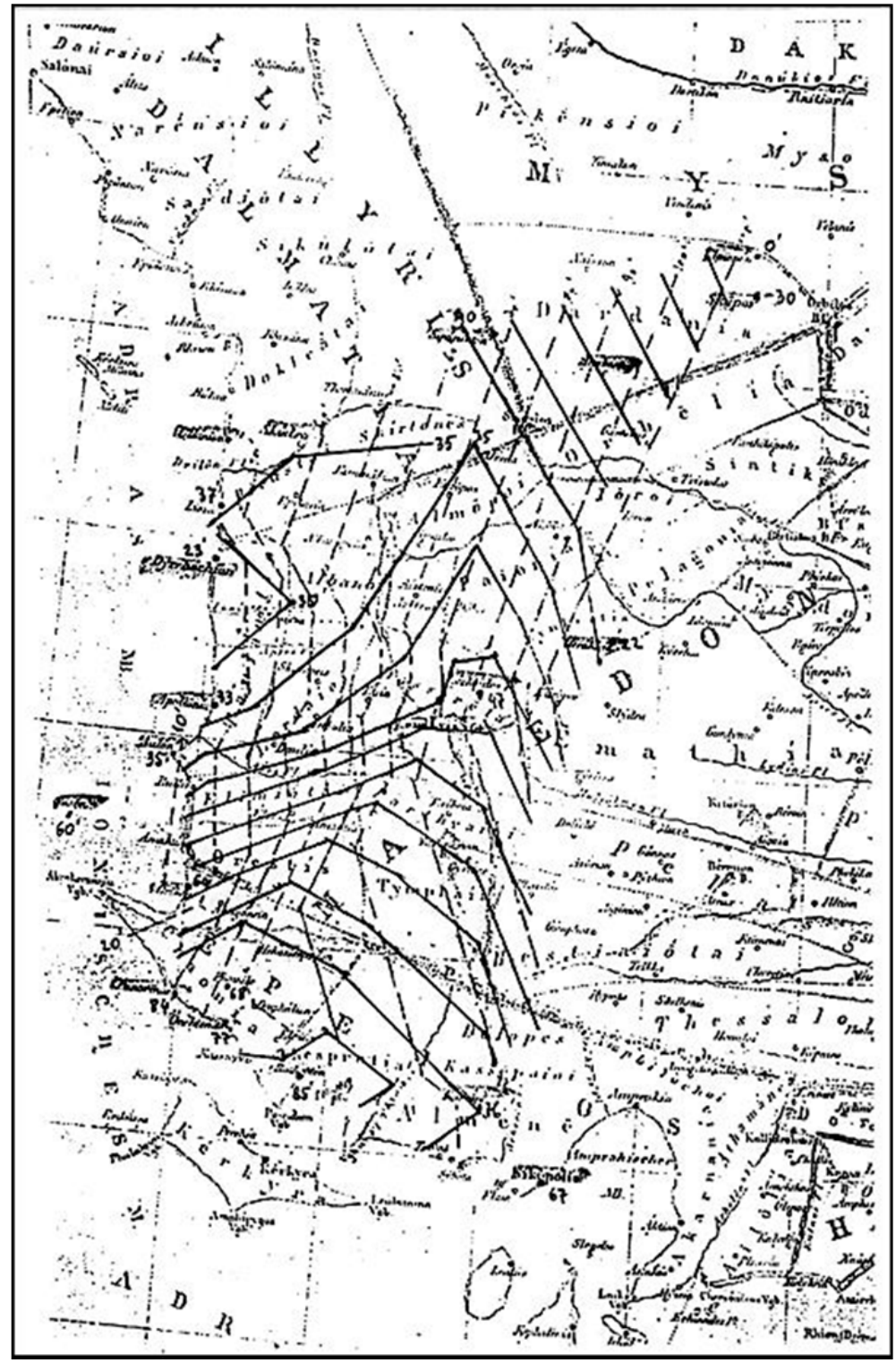

Picture 2.1: Wilberg map , year 1867 


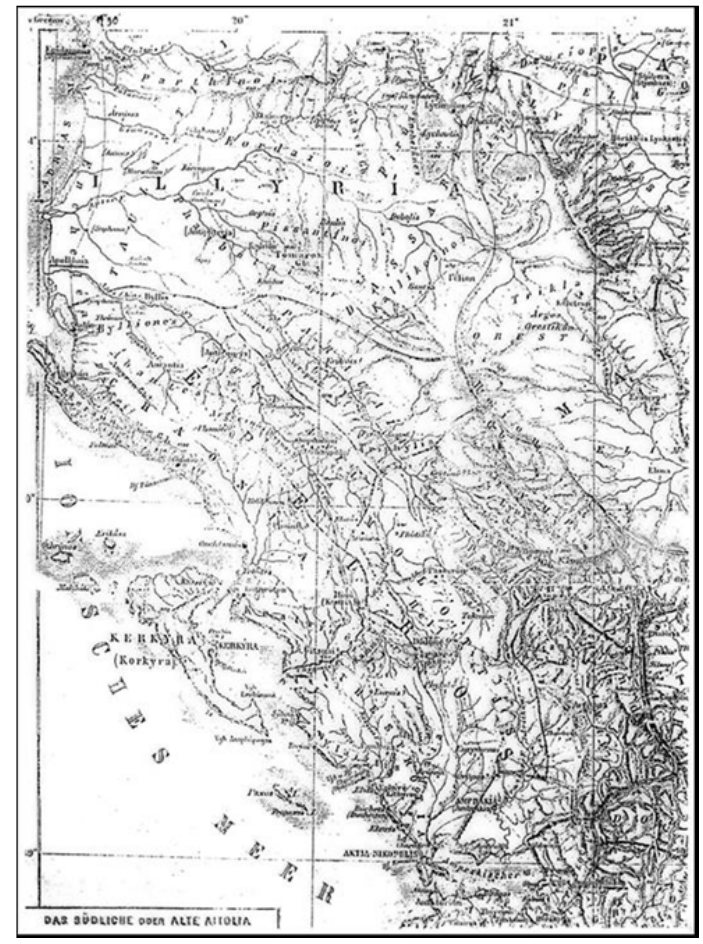

Picture.2.2: Kiepert map , year 1871 .

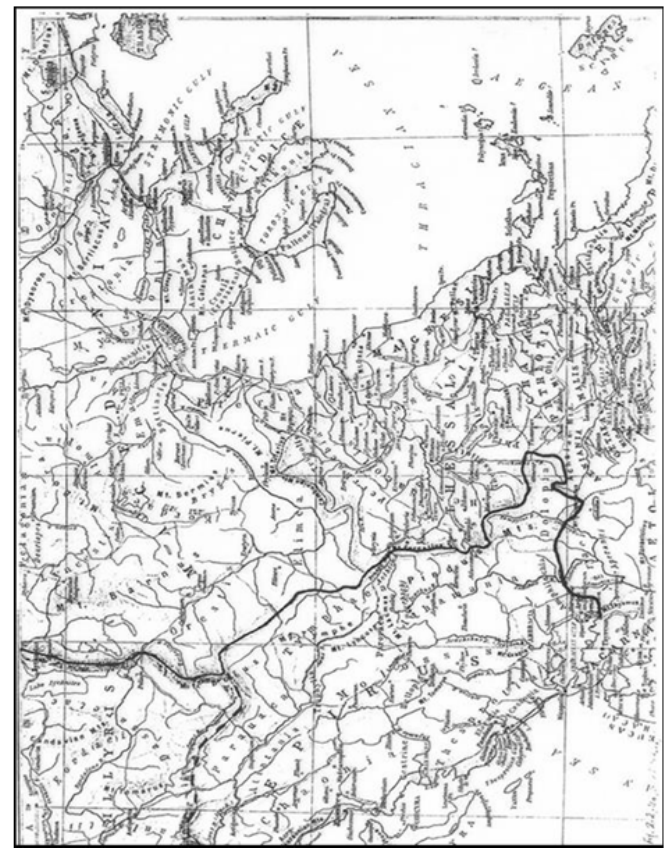

Picture 2.3: Putzger map, year 1897 


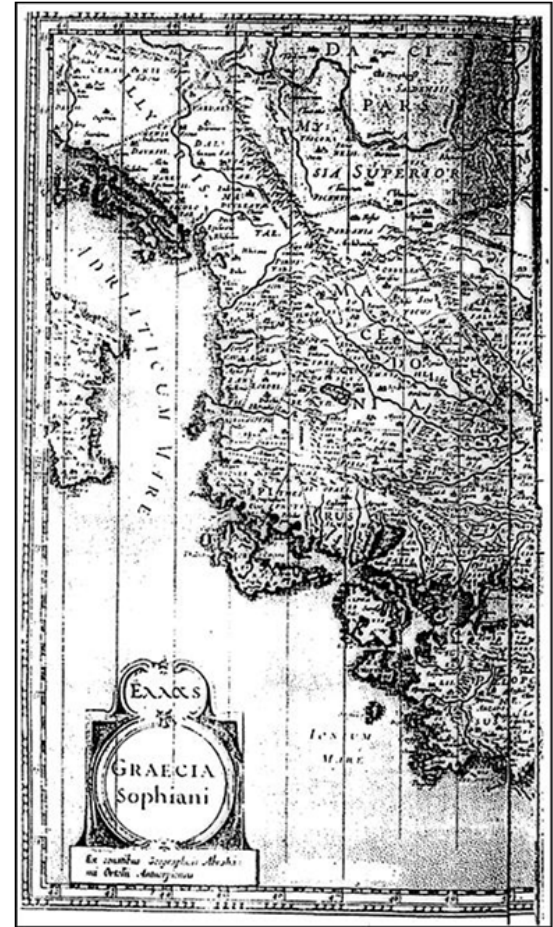

Picture 2.4: Harta e Sofjanos, year 1579

Overview 2.1: Settlements - based

\begin{tabular}{|c|c|c|c|c|c|c|c|c|}
\hline \multirow{3}{*}{$\mathbf{N}$} & \multirow{3}{*}{ Settlements -based } & \multirow{2}{*}{\multicolumn{2}{|c|}{$\begin{array}{l}\text { Geographical } \\
\text { Gaus-Kryger }\end{array}$}} & \multirow{2}{*}{\multicolumn{2}{|c|}{$\begin{array}{c}\text { coordinates } \\
\text { Ptoleme }\end{array}$}} & \multirow{2}{*}{\multicolumn{2}{|c|}{ Changes }} & \multirow{3}{*}{$\begin{array}{c}\text { Kf. } \\
\text { K }\end{array}$} \\
\hline & & & & & & & & \\
\hline & & $\mathbf{F i}$ & $\mathbf{L i}$ & F'i & L’i & $\mathbf{d F}$ & dL & \\
\hline 1 & 2 & 3 & 4 & 5 & 6 & 7 & 8 & 9 \\
\hline 1 & Podujeve (Vendenis) & $42^{\circ} 54^{\prime}$ & $21^{\circ} 13^{\prime}$ & $42^{\circ} 50^{\prime}$ & $48^{\circ} \mathrm{OoO}$ & 4 & 113 & 2.0 \\
\hline 2 & Kline(Chlina) & $42^{\circ} 36^{\prime}$ & $20 \div 35$ & $42^{\circ} 30^{\prime}$ & $46 \div 40^{\prime}$ & 6 & 70 & 1.9 \\
\hline 3. & Durres (Epidamnus) & $41^{\circ} 18^{\prime}$ & $19^{-26}$ & $40^{\circ}-55^{\prime}$ & $45^{\circ} \mathrm{OO}$ & 28 & 40 & 5.0 \\
\hline 4. & Prizren (Thermidava) & $42^{\circ} 12^{\prime}$ & $20^{\circ} 44^{\prime}$ & $41^{\circ} 45^{\prime}$ & $47^{\circ} \mathrm{OO}$ & 28 & 74 & 2.0 \\
\hline 5. & Prishtine (Ulpiana) & $42^{\circ} 40^{\prime}$ & $21^{\circ} 10^{\prime}$ & $42^{\circ} 10^{\prime}$ & $48 \div 30^{\prime}$ & 30 & 146 & 2.3 \\
\hline 6. & Peje (Siparantum) & $42^{\circ} 40^{\prime}$ & $20^{\circ} 17^{\prime}$ & $42^{\circ} 10^{\prime}$ & $46 \div 30^{\prime}$ & 30 & 78 & 2.3 \\
\hline 7. & Bajice (Arribant) & $42^{\circ} 33^{\prime}$ & $20^{\circ} 55^{\prime}$ & $42^{\circ} \mathrm{OO} \mathrm{o}^{\prime}$ & $47^{\circ} 30^{\prime}$ & 33 & 101 & 2.0 \\
\hline 8 & Apolonia & $40^{\circ} 44^{\prime}$ & $19^{\circ} 28$ & $40^{\circ} 10^{\prime}$ & $45^{\circ} \mathrm{O} 5^{\prime}$ & 34 & 43 & 4.6 \\
\hline 9. & Vlore(Aulona & $40^{\circ}-8^{\prime}$ & $19^{\circ} \mathbf{2} 8$ & $39^{\circ} 55^{\prime}$ & $44^{\circ} 50^{\prime}$ & 33 & 32 & 4.4 \\
\hline 10 & Lezhe(Lissus) & $41^{\circ} 47^{\prime}$ & $19 \div 39$ & $41^{\circ} 10^{\prime}$ & $45^{\circ} \mathrm{OO}$ & 37 & 27 & 22 \\
\hline 11 & Oher (Lychnidos) & $41^{\circ} 08^{\prime}$ & $20 \div 48$ & $40^{\circ} 0^{\prime}$ & $47^{\circ} 40^{\prime}$ & 48 & 118 & 2.3 \\
\hline 12 & Sazan & $40^{\circ} 30^{\prime}$ & $19^{\circ} \div 6$ & $39^{\circ} 30^{\prime}$ & $44^{\circ} 10^{\prime}$ & 60 & o & 0.0 \\
\hline 13 & Orikum & $40^{\circ} 19^{\prime}$ & $19^{\circ} 25$ & $39^{\circ} 15^{\prime}$ & $45^{\circ} \mathrm{OO}$ & 64 & 41 & 5.6 \\
\hline 14 & Nikopoli & $39^{\circ} \mathrm{O} 2{ }^{\prime}$ & $20 \div 44$ & $37^{\circ} 55^{\prime}$ & $47^{\circ} 25^{\prime}$ & 67 & 107 & 2.3 \\
\hline 15 & Finiq & $39^{\circ} 55^{\prime}$ & $20 \div 03$ & $38 \div 45^{\prime}$ & $45^{\circ} 20^{\prime}$ & 70 & 23 & 1.5 \\
\hline 16 & Sarande (Ochensmo) & $39^{\circ} 52^{\prime}$ & $20^{\circ} \mathrm{O} 1$ & $38 \div 35$ & $45^{\circ} 20^{\prime}$ & 77 & 25 & 1.6 \\
\hline 17 & Kassiope (Epir) & $39^{\circ} 36^{\prime}$ & $20 \div 32$ & $38 \div 16$ & $47^{\circ} \mathrm{OO}^{\prime}$ & 80 & 94 & 2.3 \\
\hline 18 & Porto Palermo & $40^{\circ} 03^{\prime}$ & $19^{\circ} 48^{\prime}$ & $38 \div 40^{\prime}$ & $45^{\circ} \mathrm{Oo}$ & 83 & 18 & 1.6 \\
\hline
\end{tabular}

$\sum=812 \quad 1150$

$X_{\text {mes }}=45.111 \quad 63.89$ 
We point out that in all the sources used, there is no data on the ancient city of Berat. Knowing the coordinates of this city would better specify the process of identification.

From Picture 2.1 and 2.2 it is noted that as the origin of longitude, Ptolemy accepted the meridian passing through the westernmost island of the world known to him, located in the group of Canary Islands of the Atlantic Ocean.

Overview 2.2: Geographical coordinates of the settlements identified

\begin{tabular}{|c|c|c|c|c|c|}
\hline \multirow{3}{*}{$\mathrm{Nr}$} & \multirow{3}{*}{ Places to identify } & \multicolumn{4}{|c|}{ Geographical coordinates } \\
\hline & & \multicolumn{2}{|c|}{ According to the Institute of History (1965) } & \multicolumn{2}{|c|}{ According to Wilberg (1867) } \\
\hline & & Fi & $\mathbf{L i}$ & Fi & Li \\
\hline 1 & 2 & 3 & 4 & 5 & 6 \\
\hline \multicolumn{6}{|c|}{ Human Settlements } \\
\hline 1 & Albanopoli & $41^{\circ} 05^{\prime}$ & $46^{\circ}$ o1’ & $41^{\circ} 05^{\prime}$ & $41^{\circ}$ oo' \\
\hline 2 & Amantia 1 (Port) & $39^{\circ} 30^{\prime}$ & $44^{\circ} 55^{\prime}$ & $39^{\circ} 30^{\prime}$ & $44^{\circ} 55^{\prime}$ \\
\hline 3 & Amantia 2 & $39^{\circ} 40^{\prime}$ & 460 oo' & $39^{\circ} 40^{\prime}$ & $46^{\circ}$ oo' \\
\hline 4 & Antigone & $39^{\circ} 10^{\prime}$ & $45^{\circ} 15^{\prime}$ & $39^{\circ} 10^{\prime}$ & $45^{\circ} 15^{\prime}$ \\
\hline 5 & Arnise & $40^{\circ} 40^{\prime}$ & $45^{\circ} 20^{\prime}$ & $40^{\circ} 40^{\prime}$ & $45^{\circ} 20^{\prime}$ \\
\hline 6 & Apsalo & $41^{\circ} 05^{\prime}$ & $46^{6}=20^{\prime}$ & $45^{\circ} 20^{\prime}$ & $46^{\circ} 20^{\prime}$ \\
\hline 7 & Bylis & $39^{\circ} 45^{\prime}$ & $45^{\circ}$ oo' & $39^{\circ} 45^{\prime}$ & $45^{\circ}$ oo' \\
\hline 8 & Dauli & $40^{\circ}$ oo' & $45^{\circ} 30^{\prime}$ & $40^{\circ}$ oo' & $45^{\circ} 30^{\prime}$ \\
\hline 9 & Dibona & $40^{\circ} 10^{\prime}$ & $45^{\circ} 45^{\prime}$ & $40^{\circ} 10^{\prime}$ & $45^{\circ} 45^{\prime}$ \\
\hline 10 & Dobera & $40^{\circ} 45^{\prime}$ & $46^{\circ} 40^{\prime}$ & $40^{\circ} 45^{\prime}$ & $46^{\circ} 40^{\prime}$ \\
\hline 11 & Dolica & $39^{\circ} 40^{\prime}$ & $47^{\circ} 30^{\prime}$ & $39^{\circ} 40^{\prime}$ & $47^{\circ} 30^{\prime}$ \\
\hline 12 & Epicari & $41^{\circ} 15^{\prime}$ & $45^{\circ} 30^{\prime}$ & $41^{\circ} 15^{\prime}$ & $45^{\circ} 30^{\prime}$ \\
\hline 13 & Elima & $39^{\circ} 40^{\prime}$ & $45^{\circ} 40^{\prime}$ & $39^{\circ} 40^{\prime}$ & $45^{\circ} 40^{\prime}$ \\
\hline 14 & Estreo & $40^{\circ} 50^{\prime}$ & $46=20^{\prime}$ & $40^{\circ} 50^{\prime}$ & $46^{\circ} 20^{\prime}$ \\
\hline 15 & Evia & $40^{\circ} 15$ & $47^{\circ} 05^{\prime}$ & $40^{\circ}=15^{\prime}$ & $46^{\circ} 05^{\prime}$ \\
\hline 16 & Europo & $41^{\circ} 20^{\prime}$ & $46^{\circ} 30^{\prime}$ & $41^{\circ} 20^{\prime}$ & $46^{\circ} 30^{\prime}$ \\
\hline 17 & Eriboja & $39^{\circ} 45^{\prime}$ & $46^{\circ} 40^{\prime}$ & $39^{\circ} 45^{\prime}$ & $46^{\circ} 40^{\prime}$ \\
\hline 18 & Ekatopendon & $39^{\circ}$ oo' & $45^{\circ} 40^{\prime}$ & $39^{\circ}$ oo' & $45^{\circ} 40^{\prime}$ \\
\hline 19 & Ealon & $38 \div 30$ & $45^{\circ} 40^{\prime}$ & $38^{\circ} 30^{\prime}$ & $45^{\circ} 40^{\prime}$ \\
\hline 20 & Festo & $39^{\circ} 20^{\prime}$ & $47^{\circ} 15^{\prime}$ & $39^{\circ} 20^{\prime}$ & $47^{\circ} 15^{\prime}$ \\
\hline 21 & Girtona & $39^{\circ} 30^{\prime}$ & $46^{\circ} 5^{\prime}$ & $39^{\circ} 30^{\prime}$ & $46^{\circ} 50^{\prime}$ \\
\hline 22 & Kassiope (port) & $38 \div 25$ & $45^{\circ} 30^{\prime}$ & $38 \div 25$ & $45^{\circ} 30^{\prime}$ \\
\hline 23 & Omfalion & $38 \div 40$ & $45^{\circ} 40^{\prime}$ & $38 \div 40$ & $45^{\circ} 30^{\prime}$ \\
\hline 24 & Orma & $41^{\circ} 30$ & $46^{\circ} 45^{\prime}$ & $41^{\circ} 30$ & $46^{\circ} 45^{\prime}$ \\
\hline 25 & Sccampi & $40^{\circ} 20^{\prime}$ & $45^{\circ} 45^{\prime}$ & $40^{\circ} 20^{\prime}$ & $45^{\circ} 45^{\prime}$ \\
\hline
\end{tabular}

\subsection{Identification of ancient settlements by graph-analytical and analytical methods}

The graph-analytical method in Ptolemy's maps guarantees a more accurate picture of the geographical distribution of the settlements under study, as well as a higher geometrical accuracy, compared to existing maps, as the calculation of Ptolemy's projection and its construction is carried out for scale 1: 1000000 (while Wilberg's map has scale 1: 30000oo, while other maps have a smaller scale). The entire territory under study is divided into three zones: North, Center and South, where base areas are selected for each zone and actions are carried out independently.

For the realization of the graph-analytic method, the actions were carried out based on the position of the sites shown in the Ptolemy's cartographic projection, calculated by us, where LO = $47^{\circ} 40^{\prime}$ ', in the position of the locations, shown on the map. Wilberg (pic. 2.1) and in actions on the 1 : 500 ooo scale topographic map (pic. 2.5).

In the analytical method, polynomial formulas with eight pairs of coefficients were used to determine the transformation coefficients. By performing the corresponding actions for both 
methods and their variants, mentioned above, the values of the geographical coordinates for all the locations identified are obtained. These values differ very little from one another; for this reason, their average has been taken, on the basis of which the positions of the countries have been determined, but already in the geographical coordinate system used today by the geodeticcartographic institutions in Albania. 1: 50000 scale topographic maps were used for this purpose. The ownership of human settlements turns out to be as follows:

1- ADPICARI / EPICARI, at source [10] is said to belong to Puka. But according to Ptolemy's coordinates: $\mathrm{F}=41^{\circ} 15$ 'and $\mathrm{L}=45^{\circ} 30^{\prime}$, this settlement, after the transformations, turns out to be in the vicinity of BUKMIRES, ie. About $23 \mathrm{~km}$ south of Puka (by air).

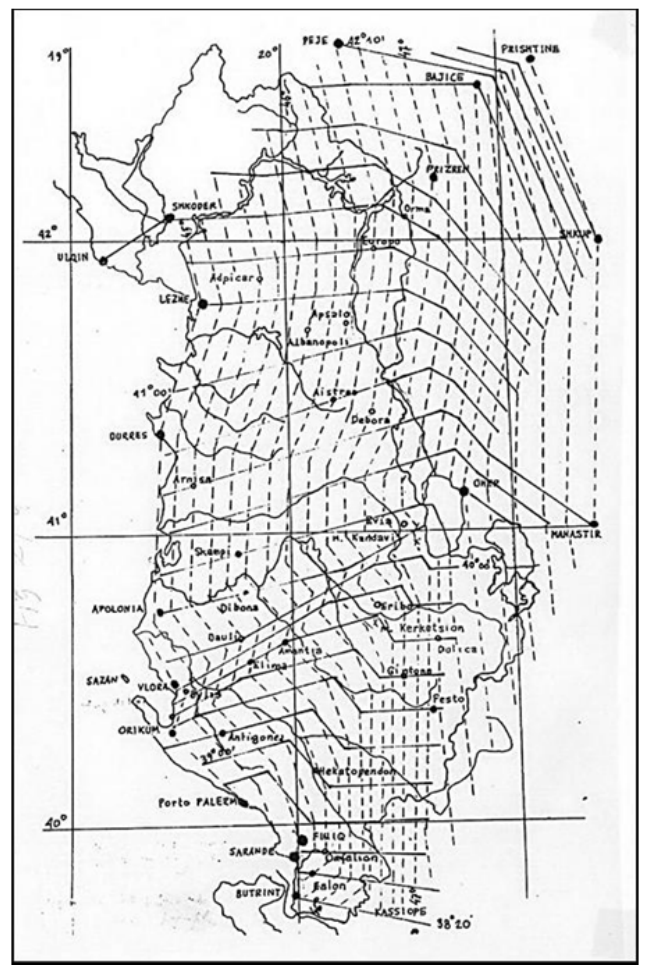

Picture. 2.5: Topographic map of scale 1: 500000 with interpolated lines

1- ALBANOPOLI, at source [10] has been identified with the church of Zgërdesh, near Kruja,

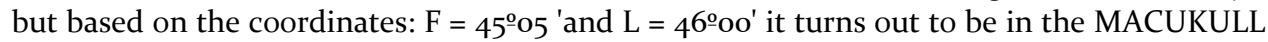
of Burrel, ie. about $34 \mathrm{~km}$ northeast of Kruja and much further south from Qinomaku, where other authors settle.

2- AISTRAIO or ESTREO, previously unidentified object, based on the coordinates: $\mathrm{F}=45^{\circ} 5^{\circ}$ 'and $\mathrm{L}=46^{\circ} \mathbf{2} \mathbf{0}^{\prime}$ ', turns out to be KARSTA of Martanesh.

3- AMANTIA, at source [10] it is identified with Plocea, but, as noted by Wilberg's map of Sofiano, and many other maps, and based on the coordinates $\mathrm{F}=39^{\circ}-30$ 'and $\mathrm{L}=44^{\circ} 55^{\circ}$ ', this denomination belongs The VIROIT Boot is therefore a port in antiquity, in the bay of Vlora. Amantia responds to Ploceau only in the map of Lapie (d. 1828) whose geographical coordinates differ greatly from those given in the reprinted works of Ptolemy. We emphasize that in these works, human settlements such as Apolonia, Antigonea, Amantia, Bylis, etc., are not unique even to the South-Eastern European space, in this case, one must 
always rely on the values of: a) the geographical coordinates given; b) in the representation of these settlements on the Ptolemy maps, and c) in the values of the new geographical coordinates obtained by analytical and / or graph-analytic methods.

4- AMANTIA, inland, with coordinates $\mathrm{F}=39^{\circ} 40$ 'and $\mathrm{L}=46^{\circ} \mathrm{oo}^{\circ}$ located between VOKOPOLES, and COROGJAT of the district of Berat; so it's not about the Plloçën.

5- ANTIGONE, in various sources it is identified sometimes with the Lekl of Tepelena and sometimes with the Germ of Gjirokastra. Based on the transformation of the original coordinates $\mathrm{F}=39^{\circ} \mathrm{o} 0$ dhe and $\mathrm{L}=45^{\circ} 15$, it turns out to be near the Mesaplikut of Mesaplik, near the Shushica River valley. This position responds best to the appearance of the denomination on Wilberg's map. On the Kiepert map Antigonea with $\mathrm{F}=40^{\circ}{ }^{\circ} 17$ 'and $\mathrm{L}=$ $19^{\circ} 4^{\prime}$ is located closer to the BRATAJ settlement, so with a slight difference with the Shalësin.

6- APSALO, previously unidentified object, according to the coordinates: $\mathrm{F}=41^{\circ} \mathrm{O} 5$ 'and $\mathrm{L}=$ 46020', turns out to be between ARREST and BULAC, on the left of the Black Drini River.

7- ARNISA, according to E.Lear, it is located north of the Terbuf marsh; according to Kiepert remains unidentified, while according to our coordinates, with $\mathrm{F}=40^{\circ} \mathbf{4 0}$ 'and $\mathrm{L}=45^{\circ} \mathbf{2 0}$ ', turns out to be between KAVAJA and GERMANY. We think that Arnisa belongs to Kavaja in antiquity, a settlement that was settled today, after the diversion of the river Shkumbin, which in the time of Ptolemy flowed into the bay of Durres.

8- BYLIS, in various sources it is identified sometimes with Hekali and sometimes with Ballsh. But, as noted by Wilberg's map, etc., in this case Bylis is a coastal settlement, which

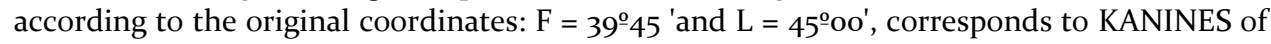
Vlora, on the map of Kiepert, Bylis responds Hekali, but as it is noticed, the object is quite displaced from the coast, i.e that we are dealing with a second designation of Bylis.

9- CASSIOPE, (port), with untransformed coordinates: $\mathrm{F}=38^{\circ} 25$ dhe and $\mathrm{L}=45^{\circ} 30$, is identified by the bay below the ruins on the DEMIT hill in Ksamil.

10- DAULI, previously unidentified object, with $\mathrm{F}=40^{\circ} \mathrm{O} 00$ 'and $\mathrm{L}=45^{\circ} 30^{\prime}$ ', is located just north of BALLSHI, so it can be identified with this ancient settlement. We also get such assurance in the presentation of this object on the map of Sofiano.

11- DEBOLI, or DIBONA, previously unidentified, with $\mathrm{F}=40^{\circ} \div 0$ 'and $\mathrm{L}=45^{\circ} 45^{\prime}$, located between BANSES and DRENOVICES.

12- DEBORA, or DEBORO, previously unidentified with $\mathrm{F}=40^{\circ} \div 5$ 'and $\mathrm{L}=46^{\circ}{ }^{\circ} \mathrm{O}^{\prime}$, identified with the LARGE.

13- DOLICA, previously unidentified, it turns out to be in PORODINE, just northwest of Korça.

14- EALON, previously unidentified, with $\mathrm{F}=38^{\circ} 30$ 'and $\mathrm{L}=45^{\circ} \mathbf{0}^{\circ}$ ', located near KODRES (Vurgu area). We find a similar position to the Hill, even in the Lauremberg map, while in the Kiepert map it is mistakenly identified with the Labova of Gjirokastra.

15- EMINAKO, previously unidentified, with $\mathrm{F}=4^{\circ} 1_{20}$ 'and $\mathrm{L}=46^{\circ} \mathrm{oo}$ ', located between DOMGJON and JUJZE, in the valley of 1 . Little Fan.

16- ELIMA, previously unidentified, with $\mathrm{F}=39^{\circ} 40$ 'and $\mathrm{L}=45^{\circ} 40^{\circ}$, located between ZHULES and NINESH-IT of Mallakastra.

17- ERIBOJA, previously unidentified, with $\mathrm{F}=39^{\circ} 45$ 'and $\mathrm{L}=46^{\circ} 40^{\prime}$ ', located between BROZDOVEC and OSOJE.

18- EUROPA, previously unidentified, with $\mathrm{F}=41^{\circ} \mathbf{2 0}$ 'and $\mathrm{L}=46^{\circ} \mathbf{3 0}^{\circ}$ ', located near KOLOSJAN, south of Kukes.

19- EVIA, previously unidentified, with $\mathrm{F}=40^{\circ}{ }^{\circ} 15$ 'and $\mathrm{L}=46^{\circ}{ }^{\circ} 0^{\prime}$ ', identified with the ancient site BELOW SELCA. This relevance is also verified by the appearance of Evia on the map of Sofiano and in particular on M. Mentille's atlas, with $\mathrm{L}=20^{\circ}-40^{\prime}$. Evia is included in the province of Dassaret, so it may not have longitude $\mathrm{L}=46^{\circ} \mathrm{o} 6^{\prime}$, (as shown in the Wilberg and Sofiano maps), but $\mathrm{L}=47^{\circ} \mathrm{o} 6^{\prime}$.

20- FESTO, previously unidentified, with $\mathrm{F}=39^{\circ} \mathbf{2 0}$ 'and $\mathrm{L}=47^{\circ} 5^{\prime}$, identified with VODICEN, 
Cologne district.

21- GINTONA, previously unidentified object, with $\mathrm{F}=39^{\circ}{ }^{\circ} 0^{\prime}$ 'and $\mathrm{L}=46^{\circ}{ }^{\circ} \mathrm{o}^{\prime}$ ', is located between PANARIT and VITHKUQ (near Vithkuq).

22- HEKATOPEDON, previously unidentified, with $\mathrm{F}=39^{\circ} \mathrm{0o}$ 'and $\mathrm{L}=45^{\circ} 40^{\prime}$ ', is identified with the PALOKASTER ruins, north of Girokastra.

23- ORMA, previously unidentified, with $\mathrm{F}=41^{\circ}-30$ 'and $\mathrm{L}=46^{\circ}-45^{\prime}$, belongs to the southern slope of Mount PIKELLIMES.

24- OMFALION, previously unidentified, with $\mathrm{F}=388^{\circ} 40$ 'and $\mathrm{L}=45^{\circ} 30^{\circ}$ ', is now well identified with MESOPOTAMINE, east of Finiq.

25- SKAMPI, previously unidentified, with $\mathrm{F}=40^{\circ} \mathbf{2 0}$ 'and $\mathrm{L}=45^{\circ} 45^{\prime}$, turns out to be in the Belsh Lakes, in the ZHAMA-CEPA-KOSOVA triangle (closest to Zama).

26- THERMIDAVA, identified with DULLE in the vicinity of Prizren, may occur if the geographical length of this object (according to Ptolemy) is $\mathrm{L}=47^{\circ} \mathrm{Oo}$ 'and not $\mathrm{L}=46^{\circ} \mathrm{Oo}$ ', since the latter is identified with TEMPLANI (preserving same latitude $F=41^{\circ} \mathbf{4} 5^{\prime}$ ).

\section{Determination of Base Sites and Sites Identified on Kiepert and Putzger Maps}

The German geographer and cartographer, H. Kiepert, during the nineteenth century, for more than 40 years of systematic study and work, created many maps of Southeast Europe, where the Albanian land occupy an important place of special interest. One of these maps is that of 1871 (pic. 2.2).

As noted, this map includes the Albanian territories located between the latitude parallels: F Jug $=38 \square$ oo 'and Fveri $=41 \square 20$ ' as well as between the meridians of longitude: Eastern $=22 \square$ oo 'and Lperend $=19 \square 20$ '.

On this map, the geographic grid is given every $1 \square$ (division of frames every 1o'), while the initial meridian is the Paris meridian (against which the other meridians are full) as well as the Greenwich meridian. The Greenwich meridian has been accepted for calculation, as it has become a tradition in Albanian cartography to this day. The difference between these two meridians is: LG - LP $=\mathbf{2} \square \mathbf{2 0}$ '.

We emphasize that the Kiepert map is built on the equivalent conical polar projection (where it does not deform the surfaces), while our topographic maps are built on the Gauss-Kryger analytic projection. However, the orthogonal coordinate changes at the node points of the geographic networks are small, for both mapping systems.

Overview 1.3 shows the geographical coordinates of the ancient sites, which were accepted as base sites, during the analytical solution of the problem under study.

Overview 1.3: Settlements

\begin{tabular}{|c|c|c|c|c|c|c|c|}
\hline \multirow[t]{3}{*}{$\mathbf{N}$} & \multirow[t]{3}{*}{ Settlements } & \multirow{2}{*}{\multicolumn{2}{|c|}{$\begin{array}{c}\text { Coordinates } \\
\text { Kiepert system }\end{array}$}} & \multicolumn{2}{|c|}{ Geographic } & \multicolumn{2}{|c|}{ Changes } \\
\hline & & & & Gauss- & system & \multirow{2}{*}{$\frac{\mathrm{d} \mathbf{F}}{\mathrm{Xi}}$} & \multirow{2}{*}{$\frac{\mathrm{dL}}{\mathrm{yi}}$} \\
\hline & & $F^{\prime}$ & L' & $\mathbf{F}$ & $\mathbf{L}$ & & \\
\hline 1 & 2 & 3 & 4 & 5 & 6 & 7 & 8 \\
\hline 1. & Durres (Epidamnus) & $41^{\circ} 18$ & $19^{\circ}-26^{\prime}$ & $41^{\circ}-18^{\prime}$ & $19^{\circ}-26^{\prime}$ & o & o \\
\hline 2. & Sazan & $40^{\circ} 30^{\prime}$ & $19^{\circ} 15^{\prime}$ & $40^{\circ} 30^{\prime}$ & $19^{\circ} 16^{\prime}$ & o & 1 \\
\hline 3. & Vlore & $40^{\circ}-28$ & $19^{\circ}-27$ & $40^{\circ}-28$ & $19^{\circ}-28^{\prime}$ & o & 1 \\
\hline 4. & Orikum & $40^{\circ}-20^{\prime}$ & $19^{\circ}-24^{\prime}$ & $40^{\circ} 19^{\prime}$ & $19^{\circ}-25^{\prime}$ & -1 & 1 \\
\hline 5. & Berat (Antipatra) & $40^{\circ} 44^{\prime}$ & $19^{\circ} 57^{\prime}$ & $40^{\circ} 44^{\prime}$ & $19^{\circ} 56^{\prime}$ & o & -1 \\
\hline 6. & Sarande & $39^{\circ} 51^{\prime}$ & $20^{\circ} \mathrm{OO}$ & $39^{\circ} 52^{\prime}$ & $20^{\circ} \mathrm{OO}$ & 1 & 1 \\
\hline 7. & Finiq & $39^{\circ} 56^{\prime}$ & $20^{\circ}-07^{\prime}$ & $39^{\circ} 55^{\prime}$ & $20^{\circ} 08^{\prime}$ & -1 & 1 \\
\hline 8. & Butrint & $39^{\circ} 45^{\prime}$ & $2 \mathrm{O}^{\circ} \mathrm{O} 3^{\prime}$ & $39^{\circ} 45^{\prime}$ & $20^{\circ} \mathrm{O} 3^{\prime}$ & o & o \\
\hline 9. & Oher & $41^{\circ} \mathrm{O} 7^{\prime}$ & $20^{\circ} 48^{\prime}$ & $41^{\circ} \mathrm{O} 77^{\prime}$ & $20^{\circ} 48^{\prime}$ & o & $\mathrm{o}$ \\
\hline 10 & Nikopoli (Preveza) & $39^{\circ} \mathrm{Oo} 0^{\prime}$ & $20^{\circ}-44^{\prime}$ & $39^{\circ} \mathrm{O} 1^{\prime}$ & $20^{\circ}-44^{\prime}$ & 1 & 0 \\
\hline 11 & Heraklea & $41^{\circ} \mathrm{O} 2^{\prime}$ & $20^{\circ}-24^{\prime}$ & $41^{\circ} \mathrm{O} 1^{\prime}$ & $21^{\circ}-23^{\prime}$ & -1 & -1 \\
\hline
\end{tabular}


Overview 1.3, Apolonia is missing as a basic object, since its coordinates in both systems vary in values: $\mathrm{dF}=5$ 'and $\mathrm{dL}=3$ '. These values contrast with the corresponding values of the other 11 countries and based on the criteria for eliminating suspicious measurements, it resulted that Apollonia had to be excluded from the base list. But Apollonia's coordinates were set in overview 1.4, to determine whether Kieperti had replaced it with any other settlement. This is also shown in his map, where "Apolonia" is connected to the Vlora-Lushnje motorway.

Given the values of the geographical coordinates of the base countries (overview 1.3), using the collinear formulas and the analytical method, the values of the transformation coefficients and other parameters are determined as shown in Figure 1.5. Then, based on the transformation coefficients, the values of the geographical coordinates of the settlements to be identified and the collinear formulas, the geographical coordinates of the same settlements, but in the Gauss-Kryger system, are determined by the analytical method. The values of these coordinates are shown in Picture 1.4. columns 4.5. Based on the transformed coordinates, the geographical locations of the settlements being identified are determined. The identification results are shown in column 6 .

\section{Overview 1.4:}

\begin{tabular}{|c|c|c|c|c|c|}
\hline \multirow{4}{*}{$\begin{array}{l}\text { Settlements } \\
1\end{array}$} & \multicolumn{4}{|c|}{ Geographical coordinates } & \multirow{4}{*}{$\begin{array}{c}\text { Affiliation } \\
6 \\
\end{array}$} \\
\hline & \multicolumn{2}{|c|}{ Kieper's map } & \multirow{2}{*}{\multicolumn{2}{|c|}{$\begin{array}{c}\text { Topographic map } \\
\text { F }\end{array}$}} & \\
\hline & \multicolumn{2}{|c|}{ F' $\quad$ L' } & & & \\
\hline & 2 & 3 & 4 & 5 & \\
\hline \multicolumn{6}{|l|}{ Human settlements } \\
\hline Arnisa & $41^{\circ} \mathrm{O} 4^{\prime}$ & $19^{\circ} 35^{\prime}$ & $41^{\circ} 04^{\prime}$ & $19^{\circ} 35^{\prime}$ & Kolushi-Rrogozhine \\
\hline Clodiana & $41^{\circ} \mathrm{O} 2$ & $19^{\circ} 51^{\prime}$ & $41^{\circ} \mathrm{O} 1^{\prime} 30$ & $19^{\circ} 51^{\prime}$ & Stacion rrugor \\
\hline Scampes & $41^{\circ} \mathrm{O} 5^{\prime}$ & $2 \mathrm{O}^{\circ} \mathrm{O} 8^{\prime}$ & $41^{\circ} \mathrm{O} 4^{\prime} 18$ & $20^{\circ} 08^{\prime} 30$ & Elbasan \\
\hline (Trojektus Genusi) & $41^{\circ} 06$ & $20^{\circ}-18^{\prime}$ & $41^{\circ}-06$ & $20^{\circ} 18^{\prime} 30$ & Shushice \\
\hline (Stefana) & $41^{\circ} 45^{\prime} 5$ & $19^{\circ} \mathbf{2 7}$ & $40^{\circ} 45^{\prime} 8^{\prime \prime}$ & $19^{0} 27^{\prime}$ & Topoje \\
\hline Apolonia & $40^{\circ} 39^{\prime}$ & $19^{\circ} \mathbf{2 5}$ & $40 \div 39 \prime 06$ & $19^{0} 2530$ & Bishan \\
\hline Byllis & $40^{\circ} 33$ & $19^{\circ} 42^{\prime}$ & $40^{\circ}-33^{\prime}$ & $19^{\circ} 42^{\prime}$ & Hekal \\
\hline Marusium & $40^{\circ} 56^{\prime}$ & $19^{\circ} 42^{\prime}$ & $40^{\circ} 56^{\prime}$ & $19^{\circ} 42^{\prime}$ & Lushnje \\
\hline Korragon & $40^{\circ} 59^{\prime}$ & $19^{\circ} 51^{\prime}$ & $40^{\circ} 5430$ & $19^{\circ} 51^{\prime}$ & Ndermjet Kosoves e Kajanit \\
\hline Gerrus (Gertunion) & $40^{\circ} 51$ & $19^{\circ} 54^{\prime}$ & $40^{\circ} 51^{\prime}$ & $19^{\circ} 54^{\prime}$ & Ne afersi te Dragotit \\
\hline Clamaria & $40^{\circ} \mathrm{o} 6^{\prime}$ & $19^{\circ} 49^{\prime}$ & $40^{\circ} 06^{\prime}$ & $19^{\circ} 49^{\prime} 30$ & Himare \\
\hline Orgesos & $40^{\circ} 50^{\prime}$ & $20^{\circ} 06$ & $40^{\circ} 49^{\prime} 55$ & $20^{\circ} 06^{\prime}$ & Tunje \\
\hline Kodrion & $40 \div 41^{\prime}$ & $2 \mathrm{O}^{\circ} \mathrm{O} 5^{\prime}$ & $40^{\circ} 411^{\prime} 30$ & $2 \mathrm{O}^{\circ} \mathrm{O} 5^{\prime}$ & Karkanjoze \\
\hline Knidos & $40^{\circ} 36$ & $20^{\circ} 08^{\prime}$ & $40^{\circ} 35,25$ & $20^{\circ} 08^{\prime}$ & Novaj \\
\hline Nymfalion (Asphalt Gruben) & $40^{\circ} 33$ & $19^{\circ} 36^{\prime}$ & $40^{\circ} 333^{\prime} 36$ & $19^{\circ} 36^{\prime}$ & Selenice \\
\hline Thronion & $40^{\circ} 31$ & $19^{\circ} 33^{\prime}$ & $40^{\circ} 31^{\prime}$ & $19^{\circ} 33^{\prime}$ & Ne lindje te Risilise \\
\hline Amantia & $40^{\circ}-22$ & $19^{\circ} 45^{\prime}$ & $40^{\circ}-22$ & $19^{\circ} 45^{\prime}$ & Plloce \\
\hline Hekatopendon & $40^{\circ} 17^{\prime}$ & $20^{\circ} 07^{\prime}$ & $40^{\circ}-16 \prime 20$ & $20^{\circ} 07^{\prime}$ & Lekli \\
\hline Omphalion (Adrianopolis) & $40^{\circ}=10$ & $20^{\circ}-16$ & $40^{\circ} 09^{\prime} 13$ & $20^{\circ} 16^{\prime} 30$ & Libohove \\
\hline Helikranon & $40^{\circ} \mathrm{O} 1^{\prime}$ & $20^{\circ} 08^{\prime}$ & $40^{\circ} 00^{\prime} 25$ & $20^{\circ} 08^{\prime} 30$ & Vanistra(Gjirokaster) \\
\hline Elaius & $39^{\circ} 57^{\prime}$ & $20^{\circ} 22^{\prime} 5^{\prime \prime}$ & $39^{\circ} 56^{\prime} 20$ & $20 \div 22 ' 30$ & Savrohon (Epir) \\
\hline Photike & $39^{\circ} 56^{\prime}$ & $20^{\circ} 38^{\prime}$ & $39^{\circ} 55^{\prime}$ & $20^{\circ} 38^{\prime}$ & Ellafotopos (Epir) \\
\hline Arinista & $39^{\circ} 55^{\prime}$ & $20^{\circ} 30^{\prime}$ & $39^{\circ} 54^{\prime} 25$ & $20^{\circ} 30^{\prime}$ & Ndermjet Dhelvinaqion e Limni (Epir) \\
\hline Patras & $41^{\circ} 111^{\prime}$ & $20^{\circ} 41^{\prime}$ & $41^{\circ} 10^{\prime}$ & $20^{\circ} 41^{\prime}$ & Struga \\
\hline Daulia & $40^{\circ}-46$ & $20^{\circ}-24$ & $40^{\circ}-45^{\prime} 15$ & $20^{\circ}-24$ & Lenias (Berat) \\
\hline Debolia & $40^{\circ} 47^{\prime}$ & $20 \div 38$ & $40^{\circ}-46$ & $20 \div 38$ & Ne perendim te Pirgut (Korçe) \\
\hline Pelion & $40^{\circ} 38^{\prime}$ & $20^{\circ} 49^{\prime}$ & $40^{\circ}-37^{\prime 25}$ & $20 \div 49^{\prime}$ & Korçe \\
\hline Bantia & $40^{\circ} 36$ & $20^{\circ} 41^{\prime}$ & $40^{\circ}-35^{\prime}$ & $20^{\circ} 41^{\prime}$ & Ravonik \\
\hline Eriboia & $40^{\circ} 23$ & $20^{\circ} 21$ & $40^{\circ}-2232$ & $20^{\circ}-21$ & Krushova \\
\hline Ilion (Kestria) & $39^{\circ} 44^{\prime}$ & $20-295^{\prime \prime}$ & $39^{\circ} 43^{\prime} 07$ & $20-29 \prime 30$ & $\begin{array}{l}2.5 \mathrm{~km} \text { ne veri te Brania (Epir) dhe } \\
\text { ne perendim te Granicapu-la }\end{array}$ \\
\hline Antigonea & $40^{\circ}-24$ & $20^{\circ} \mathrm{OO}^{\prime} 5^{\prime \prime}$ & $40^{\circ} 23^{\prime} 25^{\prime \prime}$ & $20^{\circ} 00^{\prime} 30^{\prime \prime}$ & $3 \mathrm{~km}$ ne lindje te Zhaponikes \\
\hline
\end{tabular}

F.W. Putzger, geographer and cartographer of the century. During XIX-XX centuires there were published many maps and historical and ethnographic atlases, which reflect the main historical 
events in the world, in which Albanian lands are presented on a large scale. A map (pic. 2.3) is taken from Putzger's atlas entitled "Historischer Weltatlas". Its content is also found in other historical atlases (mainly in black and white), but map 2.2 is distinguished for its particular values. The geographical network is given every $\mathbf{1}^{\circ}$, and its content is bounded by parallels $\mathrm{F}_{\text {south }}=3^{\circ} 8^{\circ}$ oo 'and $\mathrm{F}_{\text {North }}=41^{\circ} 10^{\prime}$, and between meridians with average latitude Latitudinal $=22^{\circ}$ o5 'and $\mathrm{L}_{\text {west }}=19^{\circ} 45$ '(vs. Greenwich).

This map, as well as Kiepert's map, shows some of the Albanian lands, including some of the countries of interest to us. The content of the map is built into the intermediate conical polar projection, while the base (backing) sites are sufficient for solving the task, also by the analytical method. Figure 1.6 shows the base locations and their geographical coordinates in both systems. As can be seen, in this overview the number of base locations is smaller compared to the Kiepert map, but also the number of settlements identified (overview 1.7).

Overview 1.6: Basic settlements

\begin{tabular}{|c|c|c|c|c|c|c|c|}
\hline \multirow[t]{3}{*}{$\mathbf{N}$} & \multirow[t]{3}{*}{ Settlements } & \multicolumn{2}{|c|}{ Coordinates } & \multicolumn{2}{|c|}{ Geographic } & \multicolumn{2}{|c|}{ Changes } \\
\hline & & \multicolumn{2}{|c|}{ Putzger } & \multicolumn{2}{|c|}{ Gauss-Kryger } & $\mathbf{d} \mathbf{F}$ & dL \\
\hline & & $F^{\prime}$ & $\mathbf{L}^{\prime}$ & $\mathbf{F}$ & $\mathbf{L}$ & $\mathbf{X i}$ & Ji \\
\hline 1 & 2 & 3 & 4 & 5 & 6 & 7 & 8 \\
\hline 1. & Oher (Lychnidus) & $41^{\circ}-07^{\prime}$ & $20^{\circ}-48^{\prime}$ & $41^{\circ} \mathrm{O} 7^{\prime}$ & $20^{\circ}-48^{\prime}$ & o & o \\
\hline 2. & Berat (Antipatra) & $40^{\circ}-43^{\prime}$ & $19^{\circ} 58^{\prime}$ & $40^{\circ} 44^{\prime}$ & $19^{\circ} 56^{\prime}$ & 1 & -2 \\
\hline 3. & Sarandë (Onchesmus) & $39^{\circ} 52^{\prime}$ & $2 \mathrm{O}^{\circ} \mathrm{O} 2$ & $39^{\circ} 52^{\prime}$ & $20^{\circ} \mathrm{O} 1^{\prime}$ & o & -1 \\
\hline 4. & Gjirokastër (Arqyrus) & $40^{\circ}-04^{\prime}$ & $20^{\circ} 095$ & $40^{\circ} 07$ & $20^{\circ} \mathrm{O} 75^{\prime}$ & 3 & -2 \\
\hline 5. & Finiq (Pholnice) & $39^{\circ} 53^{\prime}$ & $20^{\circ} 07$ & $39^{\circ} 55^{\prime}$ & $20^{\circ} 08^{\prime}$ & 2 & 1 \\
\hline 6. & Heraklea (Pelagonia) & $41^{\circ} \mathrm{OO}^{\prime}$ & $21^{\circ}-22^{\prime}$ & $41^{\circ} \mathrm{O} 1^{\prime}$ & $21^{\circ}-22^{\prime}$ & 1 & $\mathrm{o}$ \\
\hline 7. & Prevezë (Nikopoli) & $39^{\circ} \mathrm{Oo}$ & $20^{\circ} 44^{\prime}$ & $39^{\circ} \mathrm{O} 11^{\prime}$ & $20^{\circ} 44^{\prime}$ & 1 & $\mathrm{o}$ \\
\hline
\end{tabular}

Although the number of base locations is smaller, compared to the possibilities of the Kieper map, seven pairs of collinear equations are sufficient to accurately calculate the transformation coefficients.

The mean square error turns out to be: $\mathrm{m}= \pm 00^{\circ} 43^{\prime}$, which is $2.5 \mathrm{x}$ greater than the mean square error for the locations on the KIEPERT map. When calculating the transformation coefficients, the Gjirokastra coordinates were excluded, as they contain numerous errors, which adversely affect site identification.

From the equations constructed, from Table 1.6 and from the collinear formulas the values of the transformation coefficients and other parameters were calculated by means of (by analytical method) the conversion (transformation) of the geographical coordinates (for the identified settlements) into the Gauss-Kryger system. Based on the new coordinates (column 5.6 overviews 1.8) and topographic maps with a scale of 1: 50 ooo, the following properties are given:

Overview 1.8: settlements being identified

\begin{tabular}{|c|c|c|c|c|c|c|}
\hline \multirow{3}{*}{$\mathbf{N}$} & \multirow{3}{*}{ Settlements } & \multicolumn{4}{|c|}{ Coordinates Geographical } & \multirow{3}{*}{ affiliation } \\
\hline & & \multicolumn{2}{|c|}{ Putzger } & \multicolumn{2}{|c|}{ Gauss-Kryger } & \\
\hline & & $F^{\prime}$ & $\mathbf{L}^{\prime}$ & $\mathbf{F}$ & $\mathbf{L}$ & \\
\hline 1 & 2 & 3 & 4 & 5 & 6 & 7 \\
\hline 1 & Pelium & $40^{\circ} 41^{\prime}$ & $20^{\circ} 51^{\prime}$ & $40 \div 4109 "$ & $20^{\circ} 51^{\prime} 13^{\prime \prime}$ & Zemblak (Korçe) \\
\hline 2 & Klodiana & $41^{\circ} \mathrm{O} 3^{\prime}$ & $19^{\circ} 46^{\prime}$ & $41^{\circ} \mathrm{O} 3^{\prime} 09^{\prime \prime}$ & $19^{\circ} 46^{\prime} 13^{\prime \prime}$ & Peqin \\
\hline 3 & Scampa & $41^{\circ} \mathrm{o} 6^{\prime}$ & $20^{\circ} 05^{\prime}$ & $41^{\circ} 06^{\prime} 09^{\prime \prime}$ & $20^{\circ} 05^{\prime} 13^{\prime \prime}$ & Elbasan \\
\hline 4 & Candavia & $41^{\circ} \mathrm{O} 7^{\prime}$ & $20^{\circ}-22$ & $41^{\circ} \mathrm{O} 7^{\prime 09} "$ & $20^{\circ} 22^{\prime} 13^{\prime \prime}$ & Dardhe (Libra-zhd) \\
\hline 5 & Phanole & $40^{\circ}-08^{\prime}$ & $20^{\circ} \mathrm{O} 1^{\prime}$ & $40^{\circ} 08^{\prime} 09^{\prime \prime}$ & $20^{\circ} 011^{\prime \prime}$ & $2 \mathrm{~km}$ ne VP te Kardhiqit \\
\hline
\end{tabular}




\begin{tabular}{|c|c|c|c|c|c|c|}
\hline \multirow{3}{*}{$\mathbf{N}$} & \multirow{3}{*}{ Settlements } & \multicolumn{4}{|c|}{ Coordinates Geographical } & \multirow{3}{*}{ affiliation } \\
\hline & & \multicolumn{2}{|c|}{ Putzger } & \multicolumn{2}{|c|}{ Gauss-Kryger } & \\
\hline & & $\mathbf{F}^{\prime}$ & $\mathrm{L}^{\prime}$ & $\mathbf{F}$ & $\mathbf{L}$ & \\
\hline 1 & 2 & 3 & 4 & 5 & 6 & 7 \\
\hline 6 & Antigone & $40^{\circ}=18$ & $20^{\circ} 01^{\prime}$ & $40^{\circ}=18$ '09" & 2001'13" & Lekli \\
\hline 7 & Omfalium & $40^{\circ} 14^{\prime}$ & $20^{\circ} 22$ & $40^{\circ} 14 \% 9^{\prime \prime}$ & $20^{\circ} 22^{\prime} 13^{\prime \prime}$ & Permet \\
\hline 8 & Elaeus & $40^{\circ} \mathrm{O} 2{ }^{\prime} 5^{\prime \prime}$ & $20^{\circ}-14^{\prime}$ & $40^{\circ} 02{ }^{\prime} 39^{\prime \prime}$ & $20^{\circ} 14^{\prime} 13^{\prime \prime}$ & Libohove \\
\hline 9 & Gitana & $39^{\circ} 55^{\prime} 5^{\prime \prime}$ & $20^{\circ} 08^{\prime}$ & $39^{\circ} 55^{\prime} 39^{\prime \prime}$ & $20^{\circ} 083^{\prime \prime}$ & Delvine \\
\hline 10 & Hadriano-poli & $39^{\circ} 55^{\prime}$ & $20 \div 16$ & $39^{\circ} 55^{\prime} 09^{\prime \prime}$ & $20^{\circ} 16^{\prime} 13^{\prime \prime}$ & Jorgucat \\
\hline 11 & Helicra-num & $39^{\circ} 51^{\prime}$ & $20^{\circ} 08^{\prime}$ & $39^{\circ} 51^{\prime} 09^{\prime \prime}$ & $20^{\circ} 08^{\prime} 13^{\prime \prime}$ & Dhivri \\
\hline 12 & Dodona & $39^{\circ} 33^{\prime}$ & $20^{\circ} 28^{\prime}$ & $39^{\circ} 33^{\prime} 09^{\prime \prime}$ & $20^{\circ} 48^{\prime} 13^{\prime \prime}$ & Dodona \\
\hline
\end{tabular}

In picture 1.8 it is noted that the DODONA object is correctly identified, so this object can also be taken as a support point. From this overview also from overview 1.9, it is noted that apart from the "Scampes" facility, which is identified with Elbasan (as in overview 1.4), all other sites are identified differently.

\section{Overview 1.9:}

\begin{tabular}{|c|l|c|c|c|c|}
\hline \multirow{2}{*}{$\mathbf{N}$} & \multirow{2}{*}{ Settlements } & \multicolumn{2}{|c|}{ Identification } & \multicolumn{2}{c|}{ Changes } \\
\cline { 3 - 6 } & & Kiepert & Putzger & $\mathbf{d F}(\mathbf{3}-\mathbf{4})$ & $\mathbf{d L}(\mathbf{3}-\mathbf{4})$ \\
\hline $\mathbf{1}$ & $\mathbf{2}$ & $\mathbf{3}$ & $\mathbf{4}$ & $\mathbf{5}$ & $\mathbf{6}$ \\
\hline $\mathbf{1}$ & Clodiana & Stacioni rrugor & Peqin & $-\mathbf{1}^{\prime} 31^{\prime \prime}$ & $+4^{\prime} 47^{\prime \prime}$ \\
\hline $\mathbf{2}$ & Omfalium & Libohovë & Përmet & $-4^{\prime} 56^{\prime \prime}$ & $-5^{\prime} 43^{\prime \prime}$ \\
\hline 3 & Antigone & Zhaponikë & Lekli & $+5^{\prime} 16^{\prime \prime}$ & - o' $^{\prime \prime} 3^{\prime \prime}$ \\
\hline 4 & Elaeus & Savrohon & Libohovë & $-6^{\prime} 19^{\prime \prime}$ & $+8^{\prime} 17^{\prime \prime}$ \\
\hline
\end{tabular}

From Picture1.9 it is noted that the differences are significant, especially for the Elaeus facility and, not only between them, but also with the identification made to the last three locations of this overview, based on the geographical coordinates given by K. Ptolemy.

\section{Supplementary Notes and Conclusions}

Various authors, Albanian and foreign, identify the name "Epidamnus" with the ancient castle at Cape Rhodon. Then, by shifting the Epidamen coordinates: $\mathrm{F}=40^{\circ} 55^{\prime}$ 'and $\mathrm{L}=45^{\circ}$ oo' to the above position (in the second variant, where LOher $=47^{\circ} 4^{\circ}$ '), we find that some ancient human settlements, located in the Apollo-Triangle, Epidamnus - Ohrid, will undergo significant shifts in their position, such as:

1. ARNISA, identified near Kavaja, shifts between LIKSHNIQ and LIKSHI, with new coordinates: $\mathrm{F}=41$ ' 18 'and $\mathrm{L}=19^{\circ} 3^{8}$ '.

2. SCAMPIS, identified with Zhamen, it is already positioned in the HIGH RANGE, with coordinates: $\mathrm{F}=40^{\circ} 58$ 'and $\mathrm{L}=19^{\circ} 49^{\prime}$.

3. ALBANOPOLI, identified near Macukull of Burrel, turns out to be on the northern slope of Rune Mountain.

If Epidamn is given latitude $\mathrm{F}=4^{\circ} \mathrm{0}^{\circ} \mathrm{O}^{\prime}$ '(as given in some sources), then we will have new positions. Thus, ARNISA will be located in the triangle MARIKAJ - KASHAR - BERXULL, with F $=41^{\circ}$ 22 'and $\mathrm{L}=19^{\circ} 38^{\prime}$ ', while SCAMPIS is between SHEZES-PAJOVA and BISHKEM with $\mathrm{F}=41^{\circ} 03$ 'and L $=19^{\circ} 49^{\prime}$.

But Epidamni is not the only human settlement of exaggerated latitude. This is also observed in other settlements (along the Adriatic coast), especially Vlora. This is also evidenced by the unequal values of latitude variations $\Delta \mathrm{F}=60$ '(between the Gauss-Kryger system and Ptolemy). Vlora, located near Sazan has $\mathrm{dF}=32$ ', Durres has $\Delta \mathrm{F}=28^{\prime}$, Lezha has $\mathrm{dF}=37$ 'and Apolonia has $\mathrm{dF}=34^{\prime}$. 
In this context, we can say that relying on the geographical coordinates of Epidamn, and on Wilberg's map, it appears as if this object is located on the Cape Rhodon. But this is only a consequence of the errors of latitude given by K. Ptoleme. This conclusion is based on cartographic logic.

In Putzger's map, the CANDAVIA settlement is identified with the Pearl of Librazhd (as shown on the map) which apparently replaces the ancient EVIA designation. But on many maps, Evia is identified with the Lower Selce, a fact that we support more.

In the case of L_Oher $=46^{\circ} 40^{\prime}$ ', some sites will be identified differently than Lher $=47^{\circ} 40^{\prime}$; while the places far from Ohrid are unchanged. This is shown in Figure 1.10.

\section{Overview 1.10:}

\begin{tabular}{|c|c|c|c|c|}
\hline \multirow{2}{*}{$\mathbf{N}$} & \multirow{2}{*}{ Settlements } & \multicolumn{2}{|c|}{$\begin{array}{c}\text { Geographical coordinates in the } \\
\text { system Gauss-Kryger }\end{array}$} & \multirow{2}{*}{ Belonging to the object } \\
\hline & & Fi & $\mathbf{L i}$ & \\
\hline 1 & Eiminakon & $42^{\circ} \mathrm{OO}$ & 20ㅇㅇ' & About $1.5 \mathrm{~km}$ to the SW of Mollekuqi \\
\hline 2 & Orma & $42^{\circ} \mathrm{O} 5^{\prime}$ & $20^{\circ} 31^{\prime}$ & $3 \mathrm{~km}$ east of Perbregu (Kukes) \\
\hline 3 & Europo & $41^{\circ}-57^{\prime}$ & $20^{\circ}-25$ & KOLOSJAN \\
\hline 4 & Adpicari & $41^{\circ} 52^{\prime}$ & $19^{\circ} 55^{\prime}$ & SIMONI (1 km in west $\mathrm{m}$. Shilor) \\
\hline 5 & Assalo & $41^{\circ} 425$ & $20^{\circ}-18$ & VAJMEDHEJ (between Arasit e Bulaçit) \\
\hline 6 & Albanopoli & $41^{\circ} 415^{\prime}$ & $20 \div 09$ & $2 \mathrm{~km}$ east of Macukull \\
\hline 7 & Estreo & $41^{\circ}-26$ & $20^{\circ} 14^{\prime}$ & KRASTA e Martaneshit \\
\hline 8 & Dobera & $41^{\circ}-235^{\prime}$ & $20^{\circ} 33^{\prime}$ & OKSHTUN I VOGEL \\
\hline 9 & Arnise & $41^{\circ} 09^{\prime}$ & $19^{0} 36.5^{\prime}$ & between Kavajes and Germenjit \\
\hline 10 & Scampi & $40^{\circ} 565^{\prime}$ & $19^{\circ} 58^{\prime}$ & ZHAMA \\
\hline 11 & Evia & $40^{\circ} 56^{\prime}$ & $20^{\circ} 16^{\prime}$ & between Selites and Mollasit \\
\hline 12 & Dibona & $40 \div 477^{\prime}$ & $19^{\circ} 48^{\prime}$ & between Kutallise and Malas-Grope \\
\hline 13 & Dauli & $40^{\circ}-37^{\prime}$ & $19^{\circ} 46^{\prime}$ & BALLSH \\
\hline 14 & Bylis & $40^{\circ}-26$ & $19^{\circ} 31.5$ & KANINA \\
\hline 15 & Amantia & $40 \div \mathbf{2 2 5}$ & $19^{\circ} \mathbf{2} 8^{\prime}$ & KEPI I VIROIT \\
\hline 16 & Eribea & $40^{\circ} 39$ & $20-26$ & between Gurkuqit and Dusharit \\
\hline 17 & Dolica & $40^{\circ} 375^{\prime}$ & $20^{\circ} 42.5^{\prime}$ & GOSKOVA E POSHTME \\
\hline 18 & Festo & $40^{\circ} 23^{\prime}$ & $20 \div 38$ & between Vodices and Gostivishtit \\
\hline 19 & Antigone & $40^{\circ} 153^{\prime}$ & $19^{\circ} 42.5^{\prime}$ & SHALES \\
\hline 20 & Hecatope-ndon & $40^{\circ} 085^{\prime}$ & $20^{\circ} 07^{\prime}$ & PALOKASTER \\
\hline 21 & Omfalion & $39^{\circ} 54^{\prime}$ & $20 \div 06$ & MESOPOTAM \\
\hline 22 & Ealon & $39^{\circ} 49^{\prime}$ & 20으' & KODRA \\
\hline 23 & Cassiope (Port) & $39^{\circ} 49^{\prime}$ & $2 \mathrm{O}^{\circ} \mathrm{O} 1^{\prime}$ & Poshte Kodres se Demit \\
\hline
\end{tabular}

We assume that the identifications in Putzger's map are more accurate than in Kiepert's, since Putzger's map was published after Kiepert's and relied on more accurate maps.

The results of this study are not conclusive, but are a good basis for discussions among history specialists, archaeologists, geographers, ethnologists and others. We believe that the problem of identifying ancient geographical sites still requires intensive and integrative work.

\section{References}

Almagia, R.: Le piu antiche rapresentationi cartografiche della regione Albanese. Roma 1914.

Armao, E.: Localita, chiese, fiumi, monti, toponimi vari di una antica carta della Albania Settentrinaale. Roma 1933.

Atlas historique: Europa 1763-1993. Budapest 1997

Bagrow, L. History of Cartography. London 1964

Bagrow, L.: Antique maps and their Cartographers. London 1970 
Bouillet, M.: Atlas Universal d'histoire et de Geographie. Paris 1877

Ceka, N.: Ilirët , Tiranë 2001

Cerabregu, M.: Kosova në hartat e vjetra. Prishtinë 1977

Coronelli, P.M.: Memoire Istoriographiche. Venezia 1697

Frano Prendi,Hasan Ceka,Selim Islami,Skender Anamali: Iliret dhe Iliria. Te Autoret Antike / Burime te Zgjedhura per Historine e Shqiperise. Universiteti Shteteror i Tiranes, Instituti i Historise, (1965)

Gervasio, M.: Lálbania antica. Bari 1940

Grand, (le).: Atlas de l'histoire mondiale. Paris 1985

Gubernatis, De: Carta d'Émpiro. Roma 1879

Hahn, J.: Albanische Studien. Jena 1854

Hecquard, H.: Histoire et description de la Haute Albanien ou Guegerie. Paris 1858

Nikolli, P.: Hartografimi i trojeve shqiptare. Studime Albanologjike nr.3. Tiranë 1997

Ptoleme, C.: La Geografia. Venezia 1613

Putzger, F.W.: Historischer Schul-Atlas. Wien 1897

Shehu, A. Nikolli, P.: Historia e hartografisë shqiptare. „Julvin 2“. Tiranë, 2001

Shehu, A., Dragovoja, M.: Shqiperia në hartat e paraçlirimit. Tirane 1984 